\title{
Atlantisk symbiose eller EU-splittelse
}

\section{Torben Krogh}

Hans Mouritzen analyserer i en lille, men indholdsmættet bog de to realistiske scenarier for de næste 10 år i forholdet mellem USA og Europa. Det sker med udgangspunkt i geopolitiske overvejelser - dog med en noget udvidet definition af dette begreb

Hans Mouritzen: Europas fremtid et euro-atlantisk geopolitisk puslespil. Dansk Institut for Internationale Studier. København. 2005. 68 s.

For de næste ti år er der to realistiske scenarier for udviklingen i det euro-atlantiske forhold. Det ene består i en videreførelse af den symbiose, der - om end vakkelvornt - har præget de første 12-13 år efter den Kolde Krig. Det andet antager, at symbiosen bliver erstattet af en europæisk - men ikke en total atlantisk splittelse. Det er disse to modsatrettede udviklingsforløb, Hans Mouritzen har gjort til omdrejningspunkt i sin lille, men overordentlig interes- sante publikation: Europas fremtid - et euro-atlantisk geopolitisk puslespil.

Som allerede angivet i titlen, spiller de geopolitiske forudsætninger en betydelig rolle i Mouritzens analyse. Men for at få anbragt de forskellige brikker rigtigt i dette store puslespil er han dog nødt til at bringe begrebet ud over dets klassiske afgrænsning. Til de geografisk betingede vilkår føjer han det, han kalder staternes "historiske beliggenheder" og hermed forbundne erfaringer, aflejret i deres respektive hukommelser. Her ser vi store forskelle i Europa, og det kan derfor ikke undre, at staterne ofte vil reagere forskelligt på de samme stimuli - 
fx udfordringen fra den amerikanske hegemon.

Netop denne udfordring står helt centralt i begge de scenarier, forfatteren anser for at være realistiske. Historisk set har især Storbritannien og Frankrig reageret forskelligt på den amerikanske dominans siden Anden Verdenskrig. Og det vil de vedblivende gøre, hver for sig støttet af en række andre europæiske stater. Derfor placerer Mouritzen da også en egentlig atlantisk splittelse - med USA på den ene side og et samlet Europa på den anden - blandt de urealistiske scenarier, på linje med "skiftende europæiske alliancer" og "tilbagefald til den Kolde Krig".

\section{Den fransk-tyske akse}

USA vil fortsat kunne regne med betydningsfulde allierede i Europa.

Det centrale spørgsmål er derfor, hvordan det indbyrdes forhold vil udvikle sig blandt de europæiske stater, både i og uden for EU. Det kan ske inden for rammerne af den euro-atlantiske symbiose, der var fremherskende fra 1990 til 2002, eller det kan ske igennem en splittelse, som den, der gjorde sig gældende i forbindelse med Irak-krigen.

Et helt centralt element i symbiosen har været den tyske afhængighed af USA. Den er ikke forsvundet, men reduceret ganske betydeligt i kraft af de ændrede magtforhold i Europa. Tyske regeringer har fået et langt større råderum end tidligere, og det blev ikke mindst manifesteret ved den markante afstandtagen fra USA's invasion i Irak. Det er imidlertid ikke ensbetydende med, at Tyskland har brudt med det symbiotiske mønster.

Det spiller så igen en stor rolle for den franske politik. Målet for den har stedse været at modvirke den amerikanske dominans, især i Europa, men samtidig har de franske præsidenter og regeringer med politisk realisme respekteret de særlige tyske behov. Sovjetimperiets sammenbrud har heller ikke ændret den franske grundopfattelse, at den europæisk orienterede politik skal føres med et fransk medlemskab af det organiserede atlantiske fællesskab som forudsætning.

\section{Geopolitikkens betydning}

Den franske linje kan forklares ud fra geopolitiske vilkår, fremhæver forfatteren. En kontinental stormagt som Frankrig har i kombination med "artsfæller" en realistisk chance for at balancere imod hegemonen. Derfor vil den reagere anderledes end en "offshore" stormagt som Storbritannien. Briterne har en lang tradition for at balancere imod kontinentale magtkoncentrationer, om fornødent med amerikansk bistand. Et splittet kontinent har altid været til britisk fordel. Endvidere kan Storbritannien opnå en nøgleposition som leder for andre USA-støtter og eventuelt som atlantisk brobygger. 


\section{LITTERATUR Atlantisk symbiose eller EU-splittelse}

På den baggrund opridser Hans Mouritzen de to scenarier.

Symbiosen indebærer, at de euroatlantiske relationer vender tilbage til normalbilledet efter den Kolde Krig. Chokket fra 11. september 2001 fortager sig efterhånden, og ingen yderligere storstilede angreb på USA finder sted. USA forbliver den eneste supermagt, men nærmer sig igen multilateralismen. Dette vil være mest markant under en demokratisk administration som traditionelt hælder mere i denne retning. De amerikanske krav på ret til at gennemføre "forebyggende angreb" bliver nedtonet. Ud over international legitimitet er det her en vigtig tilskyndelse, at de amerikanske beslutningstagere kan frygte omkostningerne ved det, der er blevet kaldt "imperial overstretch".

I dette scenario vil det være nødvendigt at sikre medsponsorering fra EU/NATO/FN til militære operationer og til genopbygning, hvor de har fundet sted. Der vil som tidligere være betydelig euro-atlantisk uenighed og konflikter inden for udvalgte områder, men de vil kunne isoleres fra den fælles interesse $i$ at projicere og sikre stabilitet og demokrati i Europa og omegn.

Det symbiotiske scenario involverer hele to kompromisser. For det første det atlantiske - hvilket vil sige selve symbiosen. $\mathrm{Og}$ for det andet et internt europæisk "kompromis om kompromisset". Det vil essentielt sige en fransk-britisk forståelse.

\section{Terrorismens betydning}

Det andet scenario kæder Hans Mouritzen tæt sammen med risikoen for nye, store terroraktioner imod USA. Hvis denne trussel fortsætter, kan det også betyde en fortsættelse af det, han kalder "den amerikanske adrenalinproduktion i form af patriotisme og utålmodighed i forhold til multilaterale løsninger". Med doktrinen om "præventiv krig", der angiveligt skal komme terrorismen i forkøbet, er antallet af mulige krigsskuepladser stort. Terrorisme kan have mange arnesteder, men verifikationen af disse er ifølge sagens natur vanskelig. Derfor er doktrinen skræddersyet til at skabe uenighed $\mathrm{om}$, hvor og hvornår der bør slås til.

Men det europæiske "kludetæppe" kan ikke handle samlet i de mangfoldige valgsituationer, der skabes af denne amerikanske kurs. Derfor vil hver stat i de store spørgsmål følge sine egne geopolitiske tilbøjeligheder. Der vil efterhånden blive dannet to separate blokke af europæiske stater, i store træk som en fastfrysning af grupperingerne fra Irak-konflikten 2002-2003. Det indre Europa ledes af Frankrig og Tyskland, mens det ydre Europa anføres af USA/Storbritannien og sandsynligvis det strategisk vigtigt beliggende Polen.

I stedet for EU/NATO-indbindingen af Tyskland, som Frankrig historisk set har lagt stor vægt på, er den 
franske gevinst i dette scenario Tysklands de facto-forpligtelse på den franske side. Tysklands gevinst er, at udsigterne for en fasttømret kontinentaleuropæisk udenrigspolitik forbedres - og derved også Tysklands uafhængighed i forhold til et unilateralistisk USA.

\section{De to riller}

At opstille scenarier er kun frugtbart, hvis de hver især kan identificere en "rille" i den europæiske udvikling, anfører Hans Mouritzen. Med det mener han, at der for hvert scenario er en vis egendynamik, når det først er kommet i gang. Det opretholder i nogen grad sig selv. Hvis derimod udviklingen kan zigzagge frit mellem to eller flere scenarier, er selve pointen med at skelne mellem dem forsvundet. "Grammofonstiften" kan hoppe fra én rille til en anden, men det kræver en markant udefrakommende påvirkning.

Med visse forbehold mener forfatteren, at der kan konstateres en kontinuitet mellem landefordelingen under Irak-konflikten og den, vi kan forvente i et splittelsesscenario. Det kan ikke undre, skriver han, da det er de samme geopolitiske ræsonnementer, der ligger til grund. Eftersom de geopolitiske forhold er relativt konstante - geografiens og beliggenhedernes uforanderlighed, erfaringernes aflejringer i de politiske kulturer - bliver også staternes positioneringer stabile. Hvis splittel- sesscenariet bliver til noget, ved vi derfor med rimelig sikkerhed, hvilke stater der vil være på hvilken side og hvorfor.

For en del staters vedkommende kan der givetvis ikke være megen tvivl om, hvor de vil placere sig. Men de forbehold, forfatteren selv henviser til, kan nu ikke betegnes som ganske ubetydelige. De vigtigste angår to så store nationer som Italien og Spanien. Som Hans Mouritzen selv skriver, har de to lande traditionelt positioneret sig som både atlantister og "gode europæere". Deres valg i en bipolær struktur inden for Europa "vil sandsynligvis afhænge af indenrigspolitik og specifikke omstændigheder".

\section{Ubehageligt for Danmark}

Det lyder rigtigt. Men dermed er begrænsningerne i den geopolitisk baserede analyse også markeret. Den kan bidrage til at forklare en god del af staternes adfærd over for hinanden. Men det er ikke tilfældigt, at forfatteren har måttet medtage et begreb som "historisk betinget" geopolitik. Til den kan vi lægge de variationer eller direkte skift, der kan blive udløst af politiske ændringer. Her leverede Spanien et klart eksempel, da en socialdemokratisk regering sidste år afløste en konservativ.

Denne betragtning skal dog ikke skygge for den kendsgerning, at Hans Mouritzen nok engang har 


\section{LITTERATUR Atlantisk symbiose eller EU-splittelse}

ydet et vægtigt og tankevækkende bidrag til analysen af international politik. Den problemstilling, han her tager op, er af vital betydning for Danmark.

Selv fremhæuer han, at de to scenarier ikke handler om, hvad forfatteren finder ønskeligt (eller det modsatte) for Danmark, Europa, verdensfreden el. lign. Men som læser er det nærliggende at gøre sig nogle overvejelser over dette spørgsmål.

I hvilken lejr, Danmark vil befinde sig under splittelsesscenariet, kan der ikke herske tvivl om, uanset om regeringen er borgerligt eller socialdemokratisk ledet. For vores eget vedkommende rækker den geopolitisk baserede analyse helt og holdent.

Men situationen vil på mange måder være politisk ukomfortabel. Vi vil stå i et voksende modsætningsforhold til store og betydningsfulde EU-partnere. Og nogen synderlig belønning - eller blot opmærksomhed - vil vi næppe kunne opnå fra USA. For Danmark vil det symbiotiske scenario derfor være en klar fordel.

At holde på to heste er en disciplin, den danske udenrigspolitik har drevet op på et ganske højt niveau. 